\title{
THE PYGMALION EFFECT IN DISTANCE LEARNING: A CASE STUDY AT THE HELLENIC OPEN UNIVERSITY
}

\author{
Maria Niari[niarimaria@gmail.com],Evaggelia Manouson [gellym@gmail.com],AntonisLionarakis \\ [alionar@eap.gr], Hellenic Open University[mmw.eap.gr], Greece
}

\begin{abstract}
The Pygmalion Effect is the positive form of self-fulfilling prophecy and shows how teacher expectations influence student performance. According to this phenomenon, higher expectations can lead to an increase in performance. In this research qualitative methodology was adopted both in data collection, and in analysis, in order to investigate the impact of the Pygmalion Effect in distance adult learning. Observation was held in two Contact Sessions of the Postgraduate Module for Open and Distance Education (EKP65) of the School of Humanities at the Hellenic Open University (HOU). Also, 22 interviews were conducted, 6 with Tutors/Advisors and 16 with students of the same Postgraduate Module. The data analysis indicates that both Tutors/Advisors and postgraduate students shape form their expectations based on the behaviour as reflected in their first contact (telephone contact, face-to-face contact, written contact through the CV). Expectations originally are positive, though this could change due to mismatched following behaviour. Tutor's expectations are expressed in verbal and non-verbal ways both in written and face-to-face communication. However, it is the non-verbal behaviour and mainly the encouragement and the support towards the students - that influences their positive mood and attitude towards the learning object and distance learning itself. In conclusion, not to reject the educational trend according to which the adult learner has developed selfmotivation, we accept that Tutor's expectations reflected in encouragement and support towards the student may influence the learning process.
\end{abstract}

\section{Abstract in Greek}

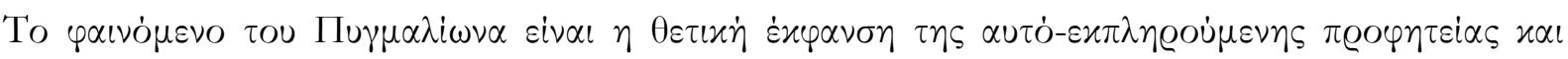

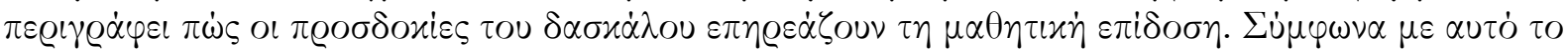

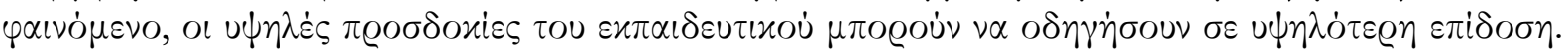

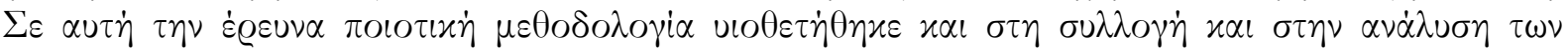

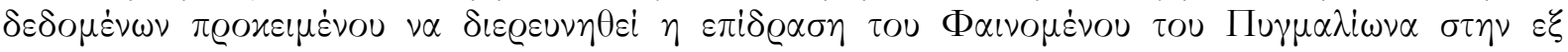

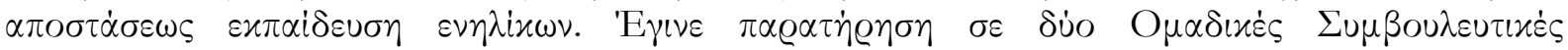

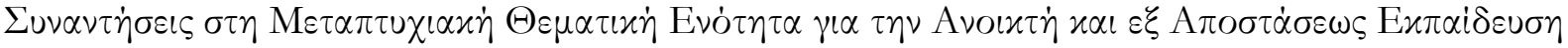

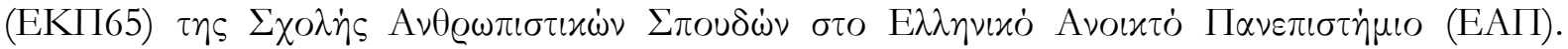

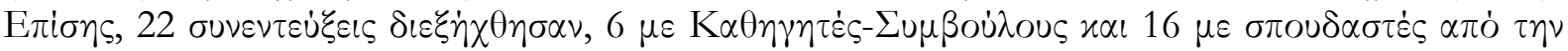

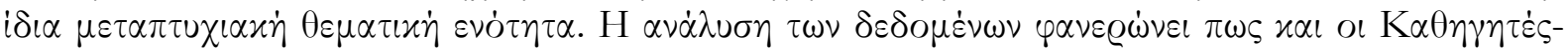

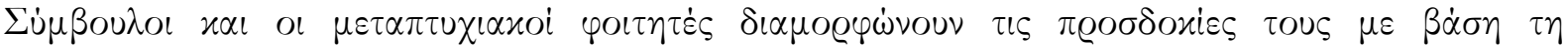

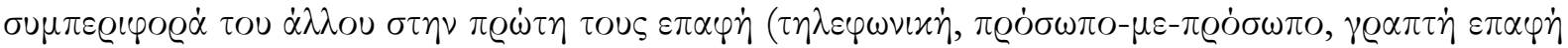

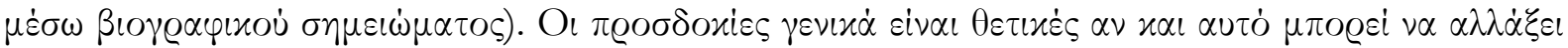

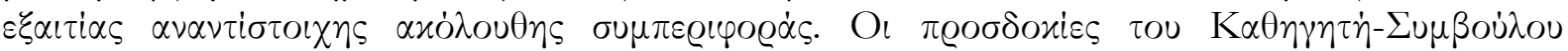

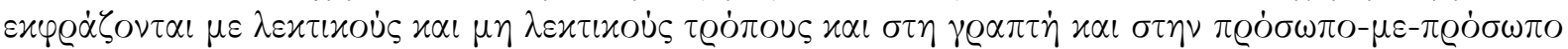

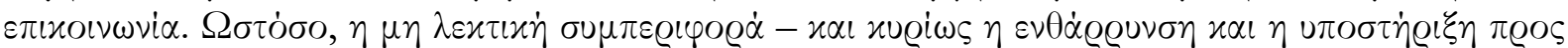

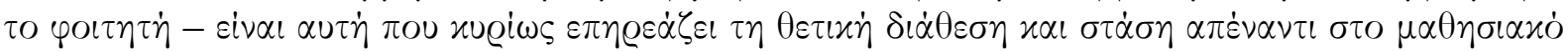

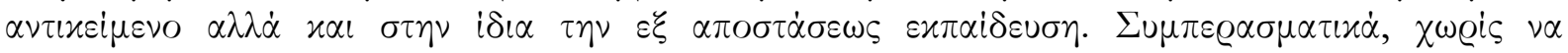

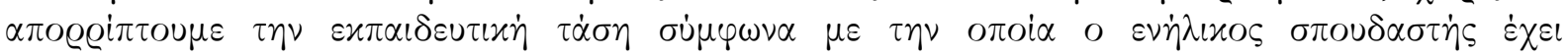




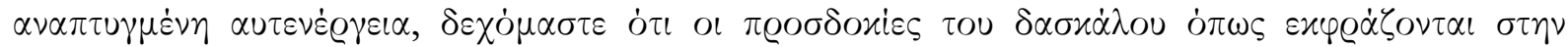

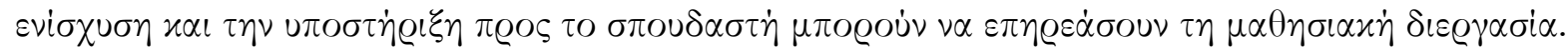

\section{Abstract in French}

L' effet Pygmalion est la forme positive de la prophétie auto-réalisatrice et montre comment les attentes des enseignants influencent la performance des élèves. Selon ce phénomène, des attentes plus élevées peuvent conduire à une augmentation des performances. Dans cette recherche, la méthodologie qualitative a été adoptée à la fois dans la collecte des données et dans l'analyse, afin d'étudier l'impact de l'effet Pygmalion dans l'apprentissage distance des adultes. Observation a eu lieu en deux sessions de contact du module de troisième cycle pour Open and Distance Education (EKP65) de l'École des sciences humaines à l'Université Ouverte Hellénique (HOU). En outre, 22 entrevues ont été menées, 6 avec les tuteurs / conseillers et 16 avec les élèves du même module de troisième cycle. L'analyse des données indique que les deux tuteurs / conseillers et étudiants de troisième cycle façonnent forment leurs attentes fondées sur le comportement comme en témoigne leur premier contact (contact téléphonique, contact face-à-face, le contact écrit par le CV). Les attentes sont à l'origine positif, bien que cela pourrait changer en raison des comportements suivants dépareillés. les attentes de Tutor sont exprimés de façon verbale et non verbale à la fois dans la communication écrite et en face-à-face. Cependant, il est le comportement non-verbal - et surtout l'encouragement et le support à l'égard des étudiants - qui influe sur leur état d'esprit positif et l'attitude envers l'objet d'apprentissage et l'apprentissage à distance lui-même. En conclusion, ne pas rejeter la tendance éducative selon laquelle l'apprenant adulte a développé l'auto-motivation, nous acceptons que les attentes reflétées dans Tutor encouragement et de support envers l'étudiant peut influer sur le processus d'apprentissage.

Keywords: Pygmalion Effect, distance learning, adult learners, expectations, encouragement, support, interaction

\section{Introduction}

In 1968, Robert Rosenthal and Lenore Jacobson published an experiment, the known Oak School, and introduced the Pygmalion Effect. The experiment was taken place at an elementary school where students took intelligence pre-tests. Rosenthal and Jacobsen informed the teachers of the names of twenty percent of the students in the school who were showing "unusual potential for intellectual growth" and would bloom academically within the year. Unknown to the teachers, these students were selected randomly with no relation to the initial test. When Rosenthal and Jacobson tested the students eight months later, they discovered that the randomly selected students who teachers thought would bloom scored significantly higher (Rosenthal \& Jacobson, 1968). The researchers argued that biased expectancies could affect reality and create selffulfilling prophecies.

Since then, many researchers have tried to replicate the experiment focusing on various aspects of the Pygmalion Effect in classroom and its impact on learning. In this article we present the results of an empirical study on the impact of Pygmalion Effect in higher distance education in Greece. It's a case study that took place at the Module for Open and Distance Education (EKP65) at the Hellenic Open University (HOU) from September 2012 till May 2013. Observation was held in two Contact Sessions of the Postgraduate Module for Open and Distance Education (EKP65) of the School of Humanities at the Hellenic Open University (HOU). Also, 22 interviews were conducted, 6 with Tutors/Advisors and 16 with students of the same Postgraduate Module (age: 28-60). 


\section{The myth of Pygmalion}

Pygmalion can be traced back to Greek mythology. He was the king of Cyprus and also a sculptor. According to Ovid, Pygmalion after seeing the Propoetides was "not interested in women", so carved a statue of a woman named Galatea. His statue was so fair and realistic that he fell in love with it. The goddess Aphrodite pitied Pygmalion and brought the statue to life. Pygmalion and Galatea, the living form of the statue, were married and had a child named Metharme.

The basic Pygmalion story has been widely transmitted and re-presented in the arts through the centuries. For example, George Bernard Shaw's Pygmalion (1912, staged 1914) in which a king lacks interest in women, but one day falls in love with a young beggar-girl, later educating her to be his queen. The play was the basis for the Broadway musical My Fair Lady (1956).

\section{The importance \& innovation of this study}

The Pygmalion Effect is not a one-way mechanism; different forms of interaction are taking place and both tutor's and student's expectations and behaviour are involved. As we strongly believe in the importance of the human factor in the process of learning - face-to-face and distance - meaning that both tutor and student play a significant part in the learning process by their engagement to learning and their interaction. As the interaction between tutors and students/learners is a field of our interest, we decided to research this phenomenon in the field of higher distance education in Greece. The initial literature review showed that only few researches have been conducted about the study of the Pygmalion Effect in distance adult learning (Rathert \& Reed, 2001; Dominguez \& Ridley, 2001), and none in Greece. In addition, we found interesting to study if and the Pygmalion effect could be a factor that could meliorate a distance adult learning experience.

\section{Research scope and objectives}

The main objective of this study was to investigate the existence and impact of the Pygmalion Effect on higher distance learning process.

More specifically, the sub-objectives were to study:

- by which ways expectations are formed for both Tutor-Advisor and distance adult learner;

- by which ways Tutor's expectations are expressed in face-to-face or written communication with the tutorial group;

- the impact of interaction between Tutor-Advisor's and learner's expectations on positive learning outcomes.

\section{Literature review}

The Pygmalion Effect is the positive form of self-fulfilling prophecy and shows that teacher expectations influence student performance. According to this phenomenon, higher expectations lead to an increase in performance. "When we expect certain behaviours of others, we are likely to act in ways that make the expected behaviour more likely to occur." (Rosenthal \& Babad, 1985). This process is also observed in every type of groups, educational, vocational or social (Meena, 2007, p.6; Mallet, 2006, p.2; Snyder \& Stukas, 1999 as ref. in Trouilloud \& Sarrazin, 2003, p.90; Manzoni \& Barsoux, 1998, p.2; Blakey, 1970, p.6). Many researchers propose theoretical models that explain or describe the Pygmalion Effect (Brophy, 1982, pp.24-25; Rist, 1977, p.301; Good \& Brophy, 1973, p.75), however Trouilloud and Sarrazin (2003; p.93) condense all these in a three-stage model. 


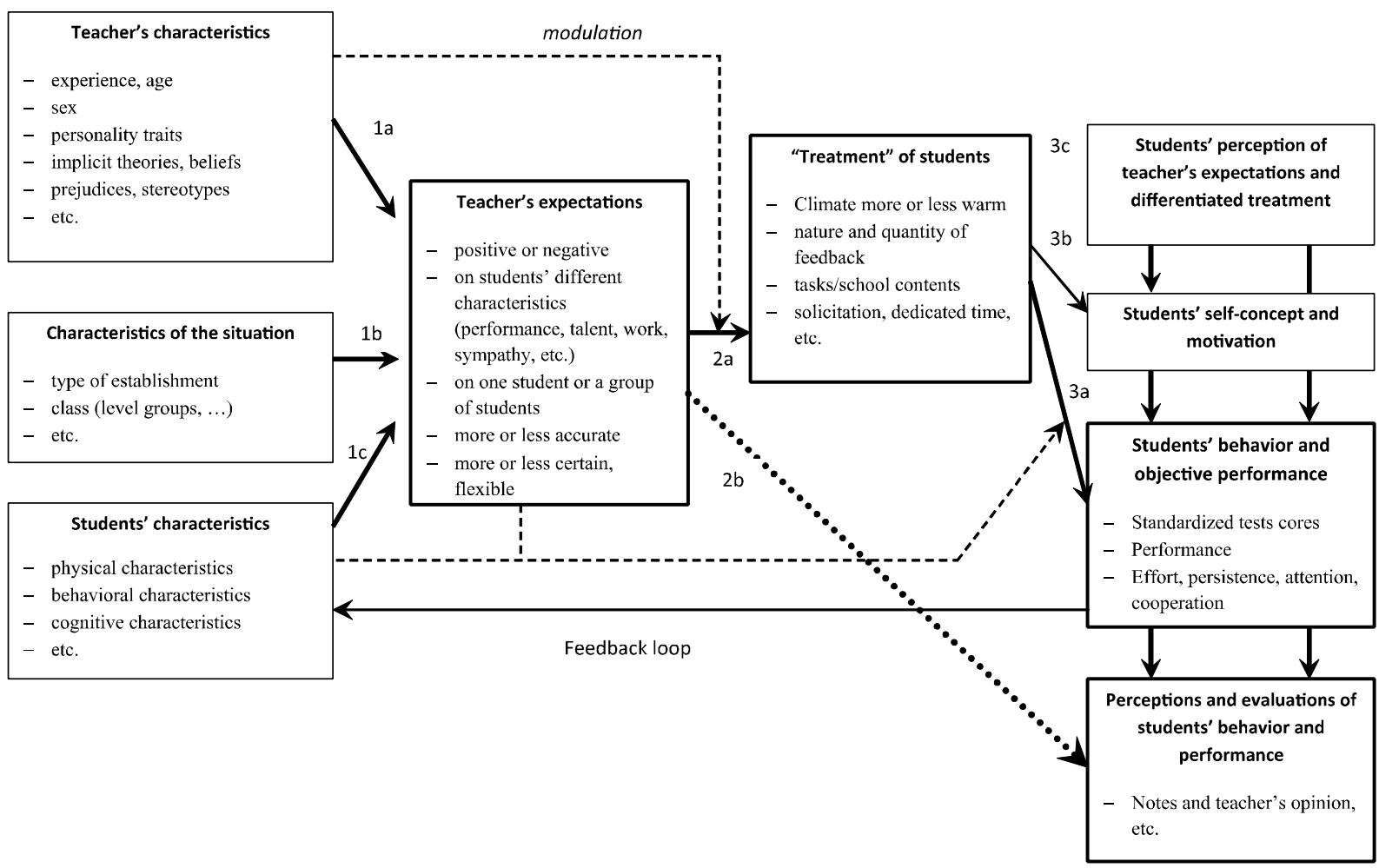

Figure 1.

According to this model, the teacher notes or collects information for students and modulates the original attitude towards them (stage 1). This creates differentiated expectations depending on the expected performance of students and thus differentiated behaviour for the various categories of students (stage 2). In fact, the teacher sends indirect constant messages to students about how they will behave or achieve academically, which leads to shape and enhance student's learning behaviour. Consequently, the student "is pushed" to a particular academic achievement and behaviour, which confirms teacher's initial expectations or estimations (stage 3).

Conditions for the efficiency and impact of this phenomenon is "durability and high frequency in the expression of expectations" (Brophy \& Good, 1970, 1974, as ref. in Giannoudis et al., 2009, p.11), as well as the interaction between clear expression of teacher's expectations and student's behavioural response (Brophy, 1982, p.17; Rist, 1977, p.301; Good \& Brophy, 1973, p.75).

Key component for the Pygmalion Effect are teacher's expectations. According to Trouilloud and Sarrazin (2003; p.95), expectations can be categorized into (a) positive - negative, (b) related to a student or group of students, (c) related to the ability and performance or to school characteristics (hardworking/lazy, independent/dependent, likeable/unlikeable, social/antisocial etc.), (d) related to one course (e.g. mathematics or physical education) or deviation in general (charisma, skills, level IQ).

In daily practice - and not under experimental conditions - expectations are usually formed based on previous school student performance (former grades, comments of colleagues, initial test / diagnostic evaluation, parental comments) or even on older brothers' performance, but can be based on generalizations - stereotypes, such as gender, appearance, socio-economic status, racial or ethnic origin (Giannoudis et al., 2009, p.11; Trouilloud \& Sarrazin, 2003, pp.95-96; Katsillis, 2005, p.136; Sprouse \& Webb, 1994, pp.5-6; Brophy, 1982, p.15; Rist, 1977, pp.296-298; Lavoie \& Adams, 1973, pp.9-12), as well. 
However, they are not expectations themselves that affect the performance and learning outcomes of students, but the teacher's unequal and differential behaviour and how students perceive and react to it (Brophy, 1982, p.34). According to Rosenthal (1974, as ref. in Trouilloud \& Sarrazin, 2003, p.97) teacher's behaviour varies according to expectations in four aspects: (a) the pedagogical content and the presentation of the work (input), (b) expression opportunities granted to students (output), (c) feedback, d) the emotional climate and verbal or non-verbal interactions with students. Noted the first and fourth aspect have more significant impact on student's conduct (Harris \& Rosenthal, 1985, as ref. in Trouilloud \& Sarrazin, 2003, p.99). Meanwhile, Cooper and colleagues (Cooper et al., 1979; pp.5-7) add another aspect to teacher behaviour: the frequency of interaction between teacher and student.

Students, even the youngest, are able to understand the diversified behaviour of the teacher, particularly the favourable treatment towards "good" students (Trouilloud \& Sarrazin, 2003; p.100). This may have implications both in intellectual development (Rosenthal \& Jacobson, 1968), and school performance (Cooper et al., 1979; Zanna et al., 1975; Hecht \& Strum, 1974; Cooper, 1971), the self-perception (Prihadi et al., 2010; Cooper, 1971), and motivation for learning (Merle, 2004; Coleman \& Jussim, 1983). According to Snyder \& Stukas (1999, as ref. in Trouilloud \& Sarrazin, 2003, p.93) the effects of teacher expectations can be of two forms: (a) confirmation of student's actual behaviour or (b) perceptual confirmation in teacher's mind.

In the field of Adult Education there are not many empirical researches which focus on the Pygmalion Effect. It is accepted that adults are more experienced compared to children, they have preferred ways of learning and have formed their personality, so the teacher's ability to affect them is limited. Some worth-mentioning researches are the following: (a) Livingston (1969, as ref. in Cherie, 2006, p.3) explored the relations between employers and employees in the working place and mainly the effect of manager's expectations in the workers performance, (b) Blakey (1970) focused on verbal cues and highlighted the existence of a relation between the teacher's expectations and the students' performance, (c) Harriet Rosenthal tried to expand his research into a new level by testing Pygmalion Effect in adults of different tribes (although his research didn't replicate the initial assumptions), (d) Skilbeck and Collins (1976) investigated the interaction between employees and employers in the working place and their research showed that the effect of expectations constitute a "fragile" parameter in social interactions and it is not always easy to be defined.

In the field of Distance Learning, Moore (1993) defined distance education as "the universe of teacher-learner relationships that exist when learners and instructors are separated by space and/or by time" (p.22). This definition includes both synchronous and asynchronous delivery formats. Transactional distance theory is important conceptually, since it proposes that the essential distance in distance education is transactional, not spatial or temporal. Advances in communications technology, which made synchronous and asynchronous interaction readily available, enabled interaction to become a key factor in distance education systems. As far as the impact of Pygmalion Effect is concerned, we could mention the researches of: (a) Rathert and Reed (2001) who conducted an experiment aiming to explore the effects of encouragement through e-mail in students' performance, (b) Dominiguez and Ridley (2001) who - in one of their studies about configuration of a model who would improve the quality of classes held from distance - admit and utilize the effect of expectations of Pygmalion-teacher during the discussion of results, (c) Suplicz (2005) who realized during his research that the difference in accomplishing a higher performance and positive attitude lies in the emotional interaction between the teacher and the student, the values and the high goals. In conclusion, the Pygmalion Effect in distance adult learning describes how teacher's expectations and the ways that those are expressed and interact with students' expectations can affect the mood and the attitude of students, reducing the distance between teacher and learners. 


\title{
Method
}

\section{Initial research plan}

At first, we intended to expand the research to all forms of interaction between Tutor-Advisor and students through a wide range of media: written communication (emails, comments to written assignments, forum), communication by telephone, face-to-face communication (Contact Sessions). Unfortunately, we were not given permission to access the different forms of written communication or by telephone; so we were restricted to the secondary data from the answers that Tutors and students gave us. We managed though to gain access to Contact Sessions at the Hellenic Open University (HOU) in Athens.

\section{The Hellenic Open University (HOU)}

The Hellenic Open University (HOU) offers undergraduate and postgraduate courses through open and distance education using a variety of methods for distance learning. For that purpose, it develops and implements appropriate learning material and blended methods of teaching. According to HOU site (http://www.eap.gr):

\begin{abstract}
"Students are provided with various learning materials that can be used from home to study: printed course material, set books, audio and video material, cd-roms / software, specially prepared for distance learning. They must plan their own time to study course material, work on course activities, and hand in assignments by the due date and also take a final course module examination at the end of each 10 month academic year. There are 5 Contact Session during the 10 month academic year in which they may participate. Each Contact Session - which is not compulsory, but is strongly recommended - is coordinated by the Tutor.
\end{abstract}

Tutorials provide students with the opportunity to solve problems and clear up misunderstandings, improve student understanding and performance, and promote tutorstudent and student-student communication. In matters of student absence, Tutors/Advisors are available to assist their students regarding the previous session.

Module courses require 4 to 6 written assignments, according to the subject area, and are evaluated by Tutor/Advisors. Written assignments are compulsory for all students and must be sent to Tutor/Advisors by the due date referred on the study plans.

Students are continuously supported by the Academic Staff and are contacted regularly."

\section{Procedure}

Due to the descriptive nature of the objective, qualitative methodology was adopted both in data collection and analysis. The data collection methods were the non-participatory observation and the semi-structured interview with open questions. We chose the non-participatory observation because it is flexible, is adjustable in small groups of people and provides significant data for social interaction (Androusou \& Petrogiannis, 2008; pp.69-70). As far as the semi-structured open-questioned interview is concerned, we chose that method instead of questionnaire in situ, because it allows a deeper investigation of the subject; the researcher is much more connected and interacts with the interviewer which gives him the chance to gain many information related to his subject (Faulkner et al., 1999; p.81). More specifically: 
Non-participatory observation was held in two Contact Sessions (March 2013) of the Postgraduate Module for Open and Distance Education (EKP65) of the School of Humanities in Hellenic Open University (HOU). The behaviour of both Tutor and students was observed in vivo and field notes were kept. We avoid using a video camera in order not to disturb the natural behaviour of participants. As soon as the aim was to observe behaviour that take place naturally into the educational context of a Contact Session of the tutorial group, we chose the semistructural, naturalistic, holistic approach (Androusou \& Petrogiannis, 2008; p.108).

More specifically, we observed the:

- non-verbal behaviour (face expressions, eye contact, gestures, body language), as it is an important factor for the formation of expectations, emotional climate and interaction;

- $\quad$ spatial behaviour, which could provide supplementary information for;

- extra-linguistic behaviour, as a way of expressing positive expectations according to literature;

- linguistic behaviour, more specifically the words of encouragement and support.

Therefore, we used an observation scale based on Weick's four categories (as ref. in Androusou \& Petrogiannis, 2008, pp.113-114).

Table 1: Observation scale

\begin{tabular}{|c|c|c|c|c|c|c|c|c|}
\hline \multirow[t]{2}{*}{ Notes } & \multicolumn{3}{|c|}{ Non verbal behaviour (body language) } & \multirow{2}{*}{$\begin{array}{c}\text { Spatial } \\
\text { behaviour }\end{array}$} & \multicolumn{2}{|c|}{ Extra-linguistic behaviour } & \multicolumn{2}{|c|}{ Linguistic behaviour } \\
\hline & $\begin{array}{c}\text { face } \\
\text { expressions }\end{array}$ & $\begin{array}{c}\text { eye } \\
\text { contact }\end{array}$ & gestures & & $\begin{array}{c}\text { Time } \\
\text { dimension }\end{array}$ & interaction & $\begin{array}{c}\text { Words of } \\
\text { encouragement }\end{array}$ & $\begin{array}{l}\text { words of } \\
\text { suppose }\end{array}$ \\
\hline
\end{tabular}

Also, 22 semi-structured open-questioned interviews were conducted, 6 with Tutors-Advisors and 16 with adult students (age: 28-51) of the same Postgraduate Module, between March and April 2013. The open-questioned interviews allow the researcher to ask for clarifications and also mark out subjects that the researcher might have not predicted (Faulkner et al., 1999; p.102). The semistructured interviews were designed according to the objective and the sub-objectives. The basic points of the questions were the following:

- formation of 'Tutor's and Students' expectations;

- their expression into behaviour (verbal and non-verbal) both in face-to-face and written communication;

- the interaction between Tutor's and student's expectations;

- the impact on positive learning outcomes/influence of the Pygmalion Effect.

Each interview was recorded and after the transcript was sent back to each participant to validate.

We chose to use interviews with both Tutors/Advisors and students in order to have data from both sides and 


\section{Participants}

The observations were held during the $4^{\text {th }}$ Contact Session of the Postgraduate Module for Open and Distance Education of HOU, in order not to disturb the formation or interaction of the educational group. We visit two different groups so as to have data from different Tutors/Advisors.

As far as the participants are concerned, we conducted interviews with 6 Tutors/Advisors from the HOU and 16 postgraduate adult students, 14 of who had attended the Module for Open and Distance Education (EKP65). All of them were experienced learners and had attended successfully at least one module at a distance. Consequently, they all were familiar with the distance learning process and could provide more accurate information about the Pygmalion Effect at a distance, as we weren't able to gain access to written communication between them and the tutor.

It is obvious that is a convenient sampling relying on example-avalanche.

We chose the HOU because it was the only statutory institution in Greece that provides studies using exclusively the methodology of distance education.

\section{Limitations}

As mentioned before, we weren't allowed to access various forms of written communication or by telephone between tutors and students. Although we were interested in using discourse analysis in written communication between Tutor-Advisor and students, we were restricted to collecting data from the interviewers. Moreover, although we intended to expand the research in other Modules and/or other Schools of HOU, we met refusal from both Tutors and student. As the time that we had in our disposal was not much (about nine months), convenient sampling was adopted. However, in order to guarantee the validity of research we used the triangulation, by using observation and interviews with both Tutors/Advisors and students.

\section{Findings}

The following table summarizes the findings. 
Table 2: Findings

\begin{tabular}{|c|c|}
\hline Sub-objective & Results \\
\hline $\begin{array}{l}\text { By which ways the } \\
\text { Tutor/Advisor shapes } \\
\text { expectations about } \\
\text { the students }\end{array}$ & 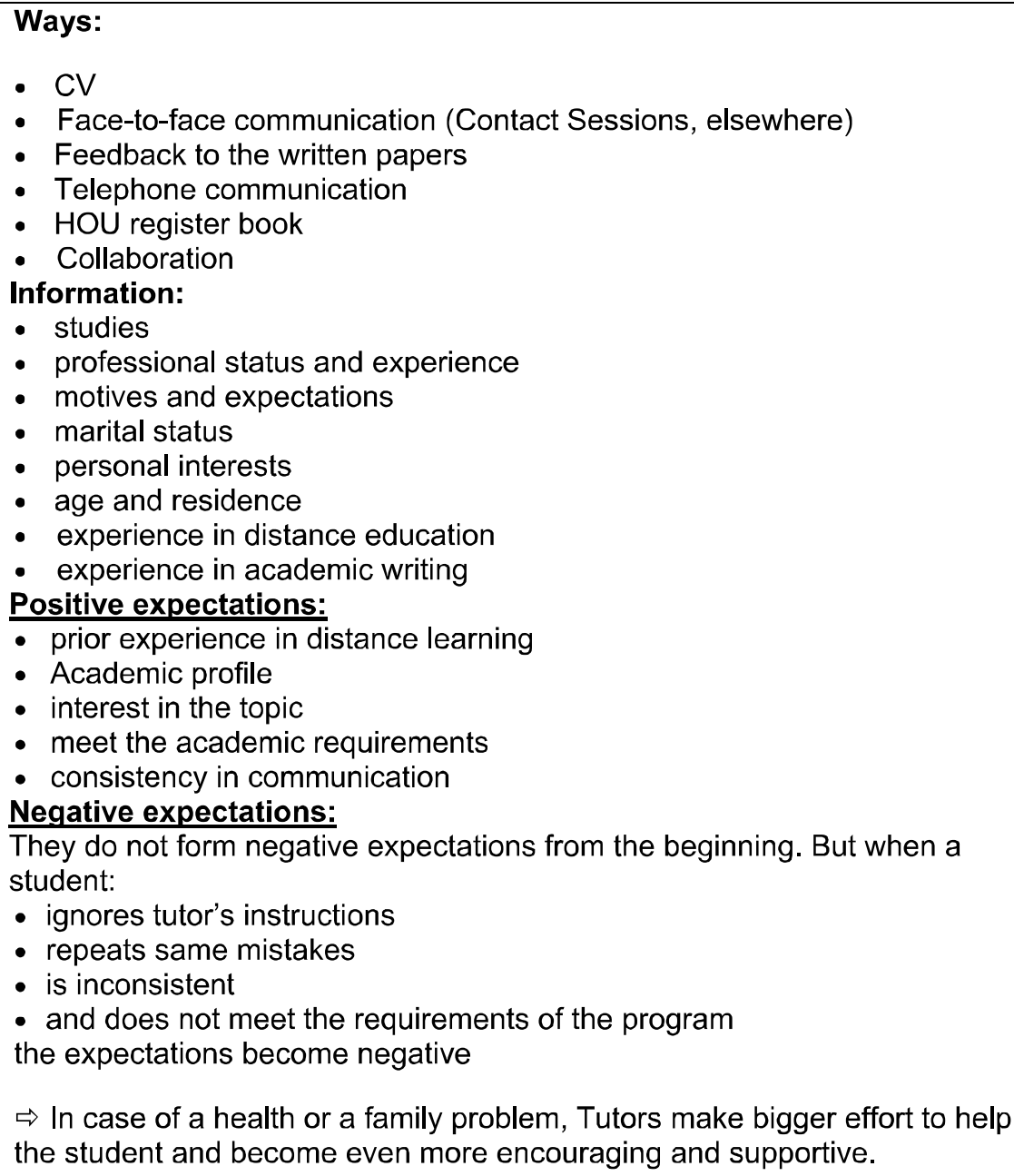 \\
\hline $\begin{array}{l}\text { By which ways the } \\
\text { students shape } \\
\text { expectations }\end{array}$ & $\begin{array}{l}\text { Ways: } \\
\text { - CV } \\
\text { - Behavior at the first Contact Session } \\
\text { - Comments from fellow students } \\
\text { - Telephone communication } \\
\text { - Information through the Internet } \\
\text { - Tutor's published papers } \\
\text { - Collaboration } \\
\text { - Feedback from the written papers } \\
\text { - Interpersonal communication } \\
\text { Positive expectations: } \\
\text { - studies } \\
\text { - experience } \\
\text { - management skills } \\
\text { - clarity } \\
\text { - collaboration } \\
\text { - support } \\
\text { Negative expectations: } \\
\text { - grandiosity/megalomania } \\
\text { - lack of experience in distance education }\end{array}$ \\
\hline
\end{tabular}




\begin{tabular}{|c|c|}
\hline $\begin{array}{l}\text { By which ways Tutor's } \\
\text { expectations are } \\
\text { expressed in face-to- } \\
\text { face communication } \\
\text { with the tutorial group } \\
\text { (contact sessions) }\end{array}$ & $\begin{array}{l}\text { Verbal behavior: } \\
\text { - phrases of encouragement } \\
\text { - first person plural } \\
\text { - superlative adjectives } \\
\text { - possessive pronouns } \\
\text { - use of students' first names, in order to express high positive expectations } \\
\text { Non-verbal behavior: } \\
\text { - many positive facial expressions (smiles, laughter etc) } \\
\text { - frequent eye-contact between Tutor-students and student-student } \\
\text { - many gestures } \\
\text { Spatial behavior: } \\
\text { Tutor - closeness to students } \\
\text { Extra-linguistic behavior: } \\
\text { - time dimension: fixed rate at presentation and instructions, slow when } \\
\text { explained questions } \\
\text { - interaction: dialogue between Tutor \& students and between students at } \\
\text { groups } \\
\text { Presence at Contact Sessions: } \\
\text { - learning by doing } \\
\text { - communication with Tutor } \\
\text { - interaction with co-students } \\
\text { - emotional involvement in the learning process } \\
\text { 'Active' students at Contact Sessions: } \\
\text { - extrovert characters } \\
\text { - experience in distance education techniques } \\
\text { Absent students: } \\
\text { - they receive email with notes } \\
\text { - written communication with both Tutor and co-students }\end{array}$ \\
\hline $\begin{array}{l}\text { By which ways Tutor's } \\
\text { expectations are } \\
\text { expressed in written } \\
\text { communication with } \\
\text { the tutorial group }\end{array}$ & $\begin{array}{l}\text { Ways: } \\
\text { - verbally } \\
\text { - friendly style } \\
\text { - encouragement \& support } \\
\text { Common emails: } \\
\text { - typical } \\
\text { - impersonal } \\
\text { Consequences: } \\
\text { - The friendly style on behalf of Tutor encourages students to keep on going } \\
\text { - The typical and impersonal way does not affect them } \\
\text { Personal emails: } \\
\text { - More friendly style } \\
\text { - Immediate answer } \\
\text { - typends on students characteristics } \\
\text { Consequences: } \\
\text { - friendly style: encouragement \& positive feelings } \\
\text { - response time: very important factor } \rightarrow \text { immediate response: } \\
\text { encouragement \& support; delay: makes them anxious } \\
\text { HOU Forum: } \\
\text { Typical communication }\end{array}$ \\
\hline
\end{tabular}




\begin{tabular}{|c|c|}
\hline $\begin{array}{l}\text { Interaction between } \\
\text { Tutor-Advisor's and } \\
\text { student's } \\
\text { expectations and its } \\
\text { impact on positive } \\
\text { learning outcomes. }\end{array}$ & $\begin{array}{l}\text { Interaction with Tutor: } \\
\text { - student try to fulfill Tutor's expectations } \\
\text { - positive feelings } \\
\text { - trust between students ad Tutor } \\
\text { - positive expectation on behalf of students as well } \\
\text { - when expectations fulfill } \rightarrow \text { positive attitude, encouragement/motivation } \\
\text { - when not } \rightarrow \text { discouragement } \\
\text { Importance of tutor's role: } \\
\text { - guidance } \\
\text { - facilitation } \\
\text { - support } \\
\text { - encouragement/motivation } \\
\text { - helps students to 'love' learning } \\
\text { Interaction with co-students: } \\
\text { Important, because: } \\
\text { - they exchange ideas and information } \\
\text { - they form peer groups } \\
\text { - they become a group - group dynamics }\end{array}$ \\
\hline \multirow{2}{*}{$\begin{array}{l}\text { The Pygmalion Effect } \\
\text { in distance adult } \\
\text { education }\end{array}$} & $\begin{array}{l}\text { Students: } \\
\text { - have experienced positive expectations } \\
\text { - examples of positive and negative expectations that fellow students have } \\
\text { experienced } \\
\text { - Tutor's positive attitude/expectation } \rightarrow \text { encouragement } \\
\text { - Tutor's negative attitude/expectation } \rightarrow \text { discouragement }\end{array}$ \\
\hline & $\begin{array}{l}\text { Tutors-Advisors: } \\
\text { - They agree that the positive attitude and support that one gives can only be } \\
\text { positive and beneficial for students } \\
\text { - Regarding adulthood: Although adult students have developed high levels } \\
\text { of self-motivation, being in a 'new' environment such as distance education } \\
\text { makes them as 'vulnerable' as children, so as interaction with Tutor may } \\
\text { affect the learning process. }\end{array}$ \\
\hline
\end{tabular}

\section{By which ways expectations are formed for both Tutor-Advisor and distance adult learner}

The collected data indicate that Tutors-Advisors form expectations about students based on: student's CV, performance in written assignments, telephone contact, face-to-face contact, and collaboration during the learning program. Tutors are interested in knowing about student's studies, professional status and experience, motives and expectations from the program, marital status, personal data and interests, experience in distance learning, in the HOU and in writing assignments. Expectations are mostly positive, especially when the student has previous experience in distance learning programs, meets the basic academic requirements and shows interest in the learning subject. Expectations tend to be negative when the student ignores teacher's instructions, repeats same mistakes, is inconsistent and does not meet the requirements of the program.

On the other hand, postgraduate adult students form expectations based on: Tutor's CV, published papers, social presence in the internet, telephone contact, face-to-face contact, classmates' comments, way of correction of written assignments and collaboration during the learning program. Students form positive expectations based on Tutor's experience in learning subject and in distance education, organizational skills, clarity, cooperation and support. Expectations tend to be negative in case of disposal of arrogance and lack of experience in distance education. 
In both cases (Tutors and students), although expectations originally are positive, this could change due to mismatched following behaviour during the learning process. Collaboration and communication between them - in other words interaction - is the basic factor for this change.

\section{By which ways Tutor's expectations are expressed in face-to-face or written communication with the tutorial group}

Tutor's expectations are expressed in verbal and non-verbal ways both in written communication and face-to-face.

In written communication, tutor may communicate via email or/and the Forum. The emails are usually more personal, and Tutor expresses himself/herself in a more friendly way than his/her presence in Forum which tends to be typical. Apart from verbal ways, students perceive Tutor's expectations through his/hers attitude and the encouragement that they receive. The friendly and intimate atmosphere encourages them to continue studying and learning, despite problems or obstacles that may have arisen. On the other hand, typical and impersonal communication discourages or has no importance to them. Last but not least, response time is very important to students; immediate response from Tutor is translated into high expectations on behalf of Tutor, encourages and reinforces their effort.

For example,

- St_8: "Mostly by telephone. We preferred to talk on the phone rather than via email. My tutor used to encourage me even when things weren't going very well. She always had a good word for me, like "You're doing great" or "I expect a lot from you". She always was encouraging by the phone but not in the emails - there she used to be more typical, impersonal, you know";

- St_13: "First of all, it is the support and encouragement that I receive and also the guidance to the written assignments. Moreover, it makes me want to respond to the Tutor while the learning material is more impersonal (...) although, the HOU learning material is appropriate for distance learning, for me it would be impossible to continue studying without Tutor/Advisor's help and support";

- T/A_2: "I have seen the matter of emotional involvement in a text ... in some cases it has positive impact, in other cases it has negative impact (...). So, I encourage (my students) whenever they have any questions, to call me on the phone; because the contact by the telephone - although is not interpersonal - is more rich in cues and messages compare to the email or the text, which is more likely to create misunderstanding. In my opinion, you should write less and communicate more";

- T/A_4: "The way we communicate with the students leads them to high performance. (...) My expectations are fulfilled because I create the appropriate emotional climate".

In Contact Sessions, Tutor's expectations are expressed both in verbal and non-verbal ways. As far as verbal ways are concerned, we noted that Tutors tend to use encouraging and rewarding phrases, first person plural, superlative adjectives, possessive pronouns and students' first names, in order to express high positive expectations. In addition, creating many opportunities for dialogue or working in groups is valued positively from students. As far as non-verbal ways are concerned, we noted frequent eye-contact between Tutor and students, many positive facial expressions (smiles, laughter etc), gestures, and closeness to students. Participating in Contact Sessions is very important for students, as they prefer learning by doing. This is also a way of emotional involvement in the learning process that pushes students to higher academic achievement. 
- St_2: "First of all, the Contact Session affects my mood; I feel much more happy and content when I attend a Contact Session where everyone is cooperating with each other, or shows empathy and we all feel members of a group";

- St_3: "It (the contact session) affects me in a positive way because everyone shares pretty much the same problems and inquiries and therefore a much more intimate climate is growing between us";

- St_13: "(the Contact Session) is very important to me because there is a sense of community growing between us. I have communicated several times with my colleagues by telephone or via emails and this has been helpful to me not to give up trying".

\section{The impact of interaction between Tutor-Advisor's and learner's expectations on positive} learning outcomes

However, it is Tutor's encouragement and support towards students that influences their positive mood and attitude towards the learning object and distance learning itself. Although adult students have developed high levels of self-motivation, being in a new environment such as distance education makes them as vulnerable as children, so as interaction with Tutor may affect the learning process. Tutor's positive expectations reflected in encouragement and support can lead to trust positive emotions and reduce the distance. In other words, interaction between Tutor and student confirms the initial positive expectations and supports the idea that Pygmalion Effect influences the learning process.

- St_1: "In my opinion, it is the way the Tutor/Advisor manages every situation that matters. Everything starts from him/her. He/She is guiding and I am performing";

- St_3: "The Tutor may have a positive or negative impact on the way I may continue my studies, depending on the feedback he/she provides. But the main effort is upon me. I am the one who completes successfully or not a module. The Tutor affects me on the way I feel about the course or the learning process itself";

- St_14: "As far as Tutor/Advisor is concerned, at a moment I was so tired and was going to quite Studies and my Tutor/Advisor helped me so much. She encouraged me. I would have quite Studies, if she wasn't there for me";

- St_4: "I believe that the relationship between Tutor/Advisor and student at a distance learning program is vital - and by relationship I mean: communication via email or by telephone, interpersonal at a contact session, guidance, feedback, encouragement, intimacy, the feeling that there is always someone there for you, to help you and listen to your problems";

- St_7: "I believe that the tutor is really important because if he/she believes in me, it reinforces my effort. If not, I feel discouraged. It affects me emotionally. (...) Either way I would have completed my studies successfully, but in this case I feel more confident and complete";

- St_7: "Of course, it has an impact on me (tutor's expectation). Especially, when I receive a negative or an unexpected comment like "you did better than I expected from you" (yes, I've been told this) it makes me feel unhappy and discouraged. I considered this comment offensive and I found it difficult to build an honest and intimate relation with this tutor. Even if the course was interesting, I found myself unhappy during the learning process. By this meaning, I believe that tutor's role is crucial to learning process itself';

- T/A_1: 'Its' (Pygmalion Effect) impact, though is weaker, is still there (in adult distance learning) as I have seen. I should be honest: ... there are students that have completed their studies because of me";

- T/A_6: "In my opinion, the Pygmalion Effect may occur everywhere as long as both sides want it (...) I think that when someone is becoming online student, is facing a part of 
himself/herself that wasn't aware of that before. So, he/she becomes vulnerable, because knowing oneself as a conventional student can be helpful until a certain point but it can be scaring not knowing how he/she will react at this new way of learning. (...) So, what the student needs at that certain moment is to be told "Don't be scared, you will make it! You are capable, but I am here to help you" and knowing that is the tutor who says that meaning an expert - can be facilitating".

To sum-up, the findings indicate that the impact of the Pygmalion Effect on distance learners involves guidance, feedback, encouragement, intimacy, the feeling that there is always there for you, to help you and listen to your problems. This way the transactional distance is being reduced and the learner accomplishes higher academic performance.

\section{Discussion-conclusion}

The research results confirm the findings of literature review that underline the importance of positive expectations as a means of reducing the distance between tutor and learner. As Harris and Rosenthal (1985, as ref. in Trouilloud \& Sarrazin, 2003, p.99) have mentioned, the input and the emotional climate through verbal or non-verbal interaction with students can positively affect their academic achievement and engagement to the learning process. Indeed in this research, the students have experienced mostly positive expectations on behalf of Tutor/Advisor and these expectations have positively affected them. Examples from both positive and negative expectations have experienced their own or fellow students and conclude that the positive attitude and expectation of the Tutor strengthens and helps them, but the negative ones can affect their attitude towards learning. They also note that the impact of the Pygmalion Effect is more intense compared to children. Tutor's expectations mostly affect them at the emotional level, confirming the relevant literature (Prihadi et al., 2010; Cooper, 1971; Merle, 2004; Coleman \& Jussim, 1983). It has to do with the encouragement and support they receive as a result of the interaction with the Tutor.

Tutors on their part agree that the encouragement and support that one gives can only have positive effects to students. Dealing with adulthood (which can, somehow, differentiate things) explain how adults when acquire a new status, that of a student of distance learning, can be as 'vulnerable' as children. As far as interaction is concerned, they consider it as a very important factor because it gives the possibility to exchange opinions and ideas with the students and also helps them create groups of inquiry with people who share the same interests. In other words, the interaction between Tutor's positive expectations and student's expectations leads to positive emotions and establishes trust relationship, which reduces the distance (Moore, 1972) and positively affects the learning process.

To sum up, the Pygmalion Effect may occur in distance learning and affects the part of the emotional involvement of the student, influencing the attitude towards the learning object, but also the role of Tutor/Advisor in distance education. The participation of the student in the learning process, the positive mood, the acceptance and understanding of his/her role as a distance learner and the satisfaction of learning depend and are influenced by Tutor's expectations and the way in which they interact with their own expectations. The completion of the studies, however, is not determined by expectations. It depends on the will, personal work and determination of the adult student himself. 


\section{Practical and theoretical consequences}

Knowledge and awareness of the importance of the role of Tutor in regard to the guidance, encouragement, and support in distance education, as highlighted by this research, leads us to suggest pedagogical exploitation of results:

- All students, regardless of age or experiences, need support and encouragement. Even if they do not express that need verbally, it does not mean that they are not affected emotionally by the Tutor. Consequently, we believe that Tutor should encourage students at every given opportunity.

- Apart from that, adult students need guidance; so the Tutor should be clear about setting goals and requirements of the academic program.

- The response time to student's messages should be as short as possible; otherwise students get anxious and/or frustrated.

- The interaction and relationship with fellow students is very important, also. So we recommend that Tutor should try to engage students in collaborative learning.

- Tutors should try to use as possible of objective data in shaping expectations and avoid stereotyping perceptual bias.

- Concluding, the value-oriented and positive approaches in distance learning are important, "as we always find what we look for. If we look for the students' deficiencies, we will surely find them, and the conflict never ends. If we look for their virtues, we will find them, too" (Suplicz, 2005; p.67). So, Tutors should form high positive expectations for their students to motivate high performance.

\section{Recommendations for further research}

The Pygmalion Effect and its impact on learning at a distance is a field for research wide open. We intend to continue studying the phenomenon. Also, we would like to suggest future researchers to:

- Expand the research field to other schools of HOU (e.g. Science and Technology School), where Tutors/Advisors are not so familiar with the practices of distance learning.

- Compare the impact of Pygmalion Effect on undergraduate and postgraduate level.

- Study the impact of tutor on student morale, self-concept and performance.

- Compare the impact of tutor's expectations and behaviour on student in Contact Sessions, by telephone and via email.

- Investigate the impact of positive and explicit comments on written assignments.

- Study the nature of tutor-student interaction via email, by telephone and in the HOU forum.

- Apply/use quantitative or/and experimental methods to replicate the existence and impact of Pygmalion Effect at the HOU.

- Study the impact of students' expectation and experience in distance education on learning process.

- Study and compare the impact of negative expectations on learning process (Golem Effect).

- Research whether the Pygmalion Effect is based on Tutor's perceptual confirmation or on the ability to make relatively accurate predictions for students, relying on his/her experience.

- The role of gender, nationality, socio-economic and marital status in the formation of Tutor's expectations. 
- The impact of Pygmalion Effect on absent students.

\section{References}

1. Blakey, M. L. (1970). The Relationship between Teacher Prophecy and Teacher Verbal Behavior and Their Effect upon Adult Student Achievement. Retrieved from http://www.eric.ed.gov, No ED 051125 (19/10/2012)

2. Brophy, J. (1982). Research on the Self-Fulfilling Prophecy and Teacher Expectations. Retrieved from http://www.eric.ed.gov, No ED 221530 (15/11/2010)

3. Coleman, L., \& Jussim, L. (1983). Perusing Teacher Expectations: A Closer Look at AffectAttribution Links. Retrieved from http://www.eric.ed.gov, No ED 239161 (15/11/2010).

4. Cooper, J. (1971). Self-Fulfilling Prophecy in the Classroom: An Attempt to Discover the Progress by Which Expectations Are Communicated. Final Report. Retrieved from http://www.eric.ed.gov, No ED 063453 (15/10/2012).

5. Cooper, H., Good, T., Blakey, S., Hinkel, G., Burger, J., Sterling, J., \& Baron, R. (1979). Understanding Pygmalion: The Social Psychology of Self-Fulfilling Classroom Expectations. Retrieved from http://www.eric.ed.gov, No ED 182642 (10/10/2012).

6. Dominguez, P. S., \& Ridley, D. R. (2001). Education; Psychology and mental health. Journal of Instructional Psychology, 28(1), 15-19.

7. Giannoudis, C., Digelidis, N., \& Papaioannou, A. (2009). Climate Motivation and Perceived Behavior of physical education teachers to disciplined - unruly students. Inquiries in Physical Education \& Sport, 7(1), 10-21

8. Good, T., \& Brophy, J. (1973). Looking in Classrooms. New York: Harper and Row

9. Hecht, M., \& Strum, I. (1974). The Self-Fulfilling Prophecy: An Adaption. Retrieved from http://www.eric.ed.gov, No ED 135464 (19/10/2012).

10. Lavoie, J., \& Adams, G. R. (1973). Pygmalion in the Classroom: An Experimental Investigation of the Characteristics of Children on Teacher Expectancy. Retrieved from http://www.eric.ed.gov, No ED 088973 (15/10/2012).

11. Mallet, M.-A. (2006). Quelle estime de soi chez les élèves bons, moyens et en difficulté? Paper presented at the 8e Biennale de l' éducation et de la formation, Lyon, 11-14 avril, 2006.

12. Manzoni, J. F., \& Barsoux, J. L. (1998). Inside the Golem Effect: How bosses can kill their subordinates motivation. Fontainebleau: INSEAD

13. Meena, L. I. (2007). Overcoming barriers in developing conversation skills: A pedagogical perspective. Proceedings of the 2007 Association for Business Communication Annual Convention, Association for Business Communication.

14. Merle, P., (2004). Mobilisation et découragement scolaires: l'expérience subjective des élèves. Education et Sociétés, 13, 193-208.

15. Moore, M. G. (1972). Leamer autonomy: The second dimension of independent leaming. Convergence, 2, 76-88.

16. Moore, M. G. (1993). Theory of transactional distance. In D. Keegan, (Ed.), Theoretical principles of distance education. New York: Routledge.

17. Prihadi, K., Hairul, N. I., \& Hazri, J. (2010). Students' Self-Esteem and their Perception of Teacher Behavior: A Study of Between-Class Ability Grouping. Electronic Journal of Research in Educational Psychology, 8(2), 707-724. 
18. Rathert, G., \& Reed, D. (2001). The Effectiveness of Electronically Communicated Encouragement on Student Performance. Retrieved from http:/ /www.eric.ed.gov, No ED 471187 (12/10/2012).

19. Rhem, J. (1999). Pygmalion In The Classroom. The National Teaching \& Learning Forum, 8(2).

20. Rist, R. C. (1977). On Understanding the Process of Schooling: The Contributions of Labeling Theory. In J. Karabel \& A. H. Hasley (Eds.), Power and Ideology in Education (p. 292305). New York: Oxford University Press.

21. Rosenthal, H. P. (1975). The Effect of Teacher Expectancy Upon the Achievement and Intelligence Test Scores of Adult Students. Retrieved from http://www.eric.ed.gov, No ED 110850 (9/10/2012).

22. Rosenthal, R., \& Babad, E. Y. (1985). Pygmalion in the gymnasium. Educational Leadership, 43(1), 36-39.

23. Rosenthal, R., \& Jacobson, L. (1968). Pygmalion in the Classroom. The Urban Review, 3(1), 1620.

24. Skilbeck, W., \& Collins, B. (1976). Transmission and Compliance with Expectations in a Simulated Supervisor - Worker Interaction. Retrieved from http://www.eric.ed.gov, No ED 140137 $(15 / 11 / 2012)$.

25. Sprouse, J., \& Webb J. (1994). The Pygmalion Effect and Its Influence on the Grading and Gender Assignment on Spelling and Essay Assessments. Retrieved from http:/ /www.eric.ed.gov, No ED 374096 (20/10/2012).

26. Suplicz, S. (2005). Psychological Aspects of E-learning. Paper presented at the VELVITT Conference, $6^{\text {th }}$ Meeting, Heraklion, 9-12 October 2005.

27. Trouilloud, D., \& Sarrazin, P. (2003). Les connaissances actuelles sur l' effet Pygmalion: processus, poids et modulateurs. Revue Française de Pédagogie, 145, 89-119.

28. Zanna, M., Sheras, P., Cooper, J., \& Shaw, C. (1975). Pygmalion and Galatea: The Interactive Effect of Teacher and Student Expectancies. Journal of Experimental Social Psychology, 11, 279287. 